\title{
Forord til RvT 70: religion og medier
}

Religion og medier som forskningsfelt har de seneste år gennemgået en markant udvikling. Det skyldes nok især de digitale mediers indpas og ikke mindst magt i verdenssamfundet i dag. Medier og mediering spiller også en afgørende rolle i og for religioner. Som Laura Feldt og Armin W. Geertz skriver i deres bidrag til dette nummer af Religionsvidenskabeligt Tidsskrift: "medier og mediering udgør centrale aspekter af hvordan alle religioner fungerer, da al kommunikation, inklusiv religiøs kommunikation, kan anskues som medieret". Dette nummer handler således ikke kun om, hvordan religion fremstilles i film eller på internettet, men også om, hvordan religioner har anvendt forskellige former for kommunikation igennem religionshistorien og hvad brugen af medier har medført af religiøse forandringer. Igennem de otte artikler vil vi møde eksempler på religioner, der medierer igennem litteratur, materielle objekter ritualer, kropsteknologier, arkitektur og spatiale rum, lyd og stemmer, udsmykning, fotografier, film, apps, sociale medier, og mange flere.

Udgangspunktet for bidragene til dette temanummer er et seminar afholdt ved Afdeling for Religionsvidenskab, Aarhus Universitet, 17.-18. dec. 2018. Seminaret inspirerede efterfølgende til otte artikler, som hver især tager det centrale forhold mellem religion og medier seriøst. Den første artikel - "Religion og medier i et religionsvidenskabeligt perspektiv" af Armin W. Geertz og Laura Feldt - præsenterer hvad vi kunne kalde state-of-the-art inden for forskningsfeltet religion og medier. Som nævnt ovenfor advokerer de to forfattere for en bred medieforståelse, som kan inkludere alle former for kommunikation og derfor for et fornyet fokus på sådan kommunikations centrale rolle igennem hele religionshistorien. Geertz og Feldts omfattende litteraturliste er et skatkammer for enhver, der ønsker at lære om, forstå og undersøge religion og medier. Indledningsartiklen danner basis for størstedelen af nummerets resterende artikler. Flere af de emner, informationer og teorier som nævnes her dukker således op i andre af nummerets artikler. Artiklerne henviser ligeledes til hinanden på kryds og tværs. Som flere tidligere temanumre i Religionsvidenskabeligt Tidsskrift kan bidragene i nummer 70 læses både som en helhed og hver for sig. Selvom der derved kan forekomme overlap, har redaktionen med vilje ikke gjort noget forsøg på at pille gentagelser ud. Det er vigtigt for os, at hver artikel kan stå alene uden andre nødvendige informationer end dem der gives i artiklen selv som referencer og fodnoter. Derfor redegør også hver enkelt artikel for sine teoretiske og metodiske udgangspunkter.

De syv artikler, som følger Geertz og Feldts indledningsartikel, kan kategoriseres og sammenstilles på forskellige måder. To artikler - "Att höra röster: Tre faser av 
lyssnande" af Simon Stjernholm og "Da Koranen blev til en app... En genforhandling af Koranens status som helligt objekt" af Johanne Louise Christiansen og Katrine Boserup Jensen - handler om forskellige nutidige manifestationer af islam og deres brug af medier og mediering. Hvor Stjernholm, igennem en præsentation af tre uafhængige forskningsprojekter om islam, advokerer for lyd som et overset, men ikke mindre væsentligt aspekt af religionsforskningen, gennemgår Christiansen og Boserup deres kvalitative studie af 13 danske muslimers forhandling af Koranen som et digitalt objekt. Der findes nemlig en del religiøse regler for, hvordan man bør behandle en fysisk koran, og spørgsmålet er, hvad der sker med sådanne regler, når mediet skifter ud i det digitale.

Også Marianne Qvortrup Fibigers artikel "Offline eller online bhakti: Fra mediering til medialisering?" undersøger overgangen fra offline til online hinduistisk bhakti-tilbedelse. I artiklen sætter Fibiger bhakti som fænomen i den hinduistiske religionshistorie i forhold til forskellige medieringsteknikker, heriblandt en online version. De tre allerede nævnte artikler behandler således det vi i dag ofte forbinder med ordet 'medier', nemlig apps, youtube-videoer, sociale medier, og film. Laura Feldts artikel i RvT 70 dykker ned i en af de sidstnævnte: Fantastic Beasts and Where to Find Them, en fantasyfilm fra det populære Harry Potter-univers. Igennem en analyse af hvordan religion fremstilles i filmen argumenterer Feldt for, at den "indlejrer sig i en bredere populærkulturel trend, hvor traditionel religion fremstilles som forstenet og autoritær, mens magi, monstre og grøn religion fremstilles positivt og tiltrækkende".

Andre af nummerets artikler behandler mere traditionelle former for kommunikation. I tråd med Christiansen og Boserups fokus på Koranens (digitale) materialitet undersøger Marianne Schleicher i sin artikel, om størrelsen af bøger i jødisk religion har en betydning for medieringen af religiøsitet. Schleicher kigger især på små eller formindskede religiøse bøger, heriblandt udgaver af Salmernes Bog og Mosebøgerne. I Tina Langholm Larsens artikel “Kolonier 'for Kirke og Folkelivets Vækst og Udvikling': Spatial mediering af dansk-amerikansk grundtvigianisme i USA, ca. 1900" er det ikke kun materialitet, men også spatialitet som præsenteres som et centralt medie. Her viser Langholm Larsen, hvordan den grundtvigianske dansk-amerikanske organisation Dansk Folkesamfund omkring 1900 især kommunikerede igennem navngivningen og etableringen af fysiske steder i form af kolonier.

Flere af RvT 70s artikler går således til temaet religion og medier med den lange religionshistorie in mente. Heriblandt kan nævnes Fibiger inden for hinduisme og Schleicher inden for jødisk religion. Niels Reehs artikel - "Religionens teknik og teknikkens religion" - tager et yderligere teoretisk spadestik og vender sig mod forholdet mellem religion og teknik, herunder medier, med basis i Martin Heideggers begreb Gestell, 'stillads'. Reeh argumenterer for, at fremkomsten af massemedier og internettet har medført en ny religiøs sammenhæng for det individuelle menneske, som bør medtænkes i den fremtidige religionsvidenskab.

Som så ofte i RvT kan vi også her præsentere grundige anmeldelser af enkeltudgivelser. Denne genre, som vi anser for særligt gavnlig for dansk religionsvidenskab, kalder vi 'review-artikler'. I dette nummer gennemgår Lars Albinus den førende tyske filosof Jürgen Habermas' seneste og meget omfattende værk, Auch eine Geschichte 
der Philosophie. Habermas gør her udstrakt brug af det begreb om aksetiden, som i flere tidligere numre af $R v T$ er blevet introduceret og diskuteret. Det er også emnet for Anders Klostergaard Petersens review-artikel af Jan Assmanns bog Achsenzeit. Eine Archäologie de Moderne; og også Assmann er tidligere blevet diskuteret i RvT. Klostergaard Petersen og Hans J. Lundager Jensen diskuterer en bog af sociologen Alexandra Maryanski, der på grundlag af den nyeste primatologisk viden vil vise at Durkheims model for kulturens (og religionens) oprindelse nu kan underbygges empirisk. Og Anders Klostergaard Petersen argumenterer med og mod Troels EngbergPetersens seneste bog om Paulus og hans nutidige relevans. Ud over disse reviewartikler er RvT 70 stolt af at kunne formidle hele syv anmeldelser af aktuelle udgivelser der er interessante for religionsvidenskaben.

Bagerst i hvert nummer af RvT er en liste over bøger som redaktionen har modtaget. Denne liste er i første omgang en kvittering og en tak til de forlag der har tilsendt bøgerne. Men den er også en indirekte opfordring til læsere om at skrive en anmeldelse. Vi får flere bøger tilsendt, end vi kan anmelde, og vi må foretage et udvalg. RvT publicerer gerne anmeldelser også af de bøger vi ikke selv har fundet en anmelder til. Så interesserede er velkomne til at henvende sig til redaktionen.

Artiklerne i dette nummer er som sædvanligt fagfællebedømte efter retningslinjerne i Uddannelses- og forskningsministeriet. Redaktionen oplever stor velvilje fra kolleger og eksperter, der gerne og med relativt kort varsel påtager sig opgaven at læse manuskripter igennem og levere nødvendig kritik og nyttige forslag til forbedringer. Redaktionen vil her gerne kvittere med stor tak til fagfællebedømmerne.

Hans J. Lundager Jensen, professor, dr. theol. Afdeling for Religionsvidenskab, Aarhus Universitet hj@cas.au.dk

Johanne Louise Christiansen, adjunkt, ph.d. Religionsstudier, Institut for Historie, Syddansk Universitet jchr@sdu.dk

Katrine Frøkjær Baunvig, lektor, ph.d. Grundtvig Centeret, Institut for Kultur og Samfund, Aarhus Universitet baunvig@cas.au.dk 